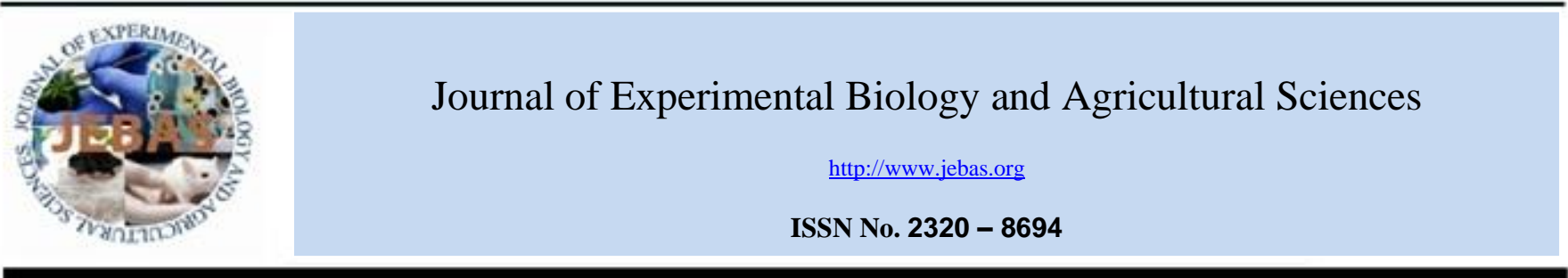

\title{
NUTRIENT REMOVAL PATTERN OF WEEDS DUE TO TRADITIONAL WEED MANAGEMENT PRACTICES IN MAIZE
}

\author{
Arunjith $\mathrm{P}^{\# *}$, P Murali Arthanari, Pooja A P \\ Department of Agronomy, Tamil Nadu Agricultural University, Coimbatore 641003, Tamil Nadu, India \\ \#Present address: Department of Agronomy, College of Agriculture, Vellayani, Thiruvananthapuram 695522, Kerala, India \\ Received - December 18, 2020; Revision - July 20, 2021; Accepted - July 25, 2021 \\ Available Online - October 20, 2021 \\ DOI: http://dx.doi.org/10.18006/2021.9(Spl-3-NRMCSSA_2021).S353.S357
}

\section{KEYWORDS}

Maize

Nutrient removal

Traditional weed management methods

Vinegar

Weeds

\begin{abstract}
Weeds compete with crops for nutrients and nutrient removal by weeds is a serious problem in a widely spaced crop like maize. Traditional weed management methods offer a wide scope for reducing the nutrient removal by weeds by effective management methods. The field experiment was conducted to study the influence of traditional weed management methods on nutrient removal by weeds in maize at Tamil Nadu Agricultural University, Coimbatore during Kharif 2017. Common salt (30\%), vinegar $(20 \%)$, and a traditional formulation containing cow urine, lemon fruit, dried fruits of Indian walnut (Terminalia chebula) in two concentrations @7.5 and $101 \mathrm{ha}^{-1}$ were used as a post-emergence spray with or without hand weeding on 45 DAS. Hand weeding at 20 and 45 DAS and weedy checks were also maintained for comparison. At 30 DAS, lower nitrogen, phosphorus, and potassium removal by weeds $\left(0.68,0.08\right.$, and $\left.0.45 \mathrm{~kg} \mathrm{ha}^{-1}\right)$ were observed in hand weeding twice on 20 and 45 DAS. Hand weeding twice on 20 and 45 DAS registered significantly lower nitrogen $\left(0.2\right.$ and $\left.1.40 \mathrm{~kg} \mathrm{ha}^{-1}\right)$, phosphorus (0.02 and $\left.0.19 \mathrm{~kg} \mathrm{ha}^{-1}\right)$ and potassium $\left(0.21\right.$ and $\left.1.48 \mathrm{~kg} \mathrm{ha}^{-1}\right)$ removal which was merely comparable with postemergence application of vinegar $20 \%$ + hand weeding on 45 DAS (0.71 and 1.83 $\mathrm{kg} \mathrm{ha}^{-1} ; 0.07$ and $0.25 \mathrm{~kg} \mathrm{ha}^{-1} ; 0.73$ and $1.94 \mathrm{~kg} \mathrm{ha}^{-1}$ ) at $60 \mathrm{DAS}$ and harvest. All the traditional weed management methods resulted in lower nutrient removal by weeds compared to the weedy check.
\end{abstract}

* Corresponding author

E-mail: arunjithp0077@gmail.com

Peer review under responsibility of Journal of Experimental Biology and Agricultural Sciences.

Production and Hosting by Horizon Publisher India [HPI] (http://www.horizonpublisherindia.in/).

All rights reserved.
All the articles published by Journal of Experimental Biology and Agricultural Sciences are licensed under a Creative Commons Attribution-NonCommercial 4.0 International License Based on a work at www.jebas.org.

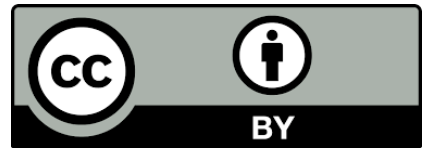




\section{Introduction}

In maize, around $30-40 \%$ of the applied nutrients during the crop growth period are usually removed by weeds which are a loss to the crop (Mundra et al., 2002). Severe weed competition and heavy drain of plant nutrients are observed when weeds and maize seeds emerge together and grow along with maize till the end of the early growth period (Lakshmi \& Luther, 2017). The maize crop is sensitive to weeds which occur at 25 to 30 days of crop and severe competition for valuable resources like soil, water, nutrients and solar radiation are observed, thus lowering the productivity of maize. Nutrients are inputs and their drain through weeds can be checked by weed management approach (Nazreen et al., 2017). Competition for nutrients between maize and weeds are influenced by type and amount of nutrient available, amount of precipitation and nature of weed species (Sivagamy et al., 2017). Herbicidal weed management fetches an important role in intensive cropping. But the indiscriminate use of herbicides and their associated environmental and ecological problems call for the alternative to chemical weed management Among the nonchemical weed management methods, traditional weed management practices fetch an important role where the knowledge shared by ancestors, methods evolved by the resource-poor tribal farmers, and natural products are executed. It is in this background, a study was conducted to assess the nutrient removal pattern of weeds as influenced by traditional weed management practices in maize.

\section{Materials and Methods}

The experiment was conducted at the Eastern block of the farm (Field No 75) of Tamil Nadu Agricultural University, Coimbatore $\left(11^{0} \mathrm{~N}\right.$ latitude, $77^{0} \mathrm{E}$ longitude, and altitude of $426.7 \mathrm{~m}$ above MSL) during Kharif, 2017 with maize as the test crop. The experiment was laid out in randomized block design with ten treatments replicated thrice. The soil was sandy loam in texture, moderately alkaline, high in organic carbon, low in available nitrogen, medium in available phosphorus, and high in available potassium. The recommended dose of fertilizers @ 250:75:75 kg NPK ha ${ }^{-1}$ were applied to the crop. The full dose of phosphorus and potassium and 25 percent of nitrogen were applied as basal and the remaining $\mathrm{N}$ was top-dressed at $25(50 \%)$ and 45 DAS $(25 \%)$.

Traditional weed management practices include spraying of various inputs as early post emergence (EPOE) at 2-6 leaf stage of weeds $\left(15^{\text {th }}\right.$ day of sowing) or as post emergence (POE) at the $20^{\text {th }}$ day of sowing. Treatments include EPOE $30 \%$ common salt, POE vinegar 20\%, EPOE traditional formulation containing cow urine, lemon fruit, and Indian walnut (Terminalia chebula) at two concentrations viz., $101 \mathrm{ha}^{-1}$ and $7.51 \mathrm{ha}^{-1}$ with or without hand weeding at 45 days after sowing (DAS). Hand weeding twice at 20 and 45 DAS and weedy checks were also maintained for comparison. One month old cow urine (10 litre), finely grounded powder of dried fruits of $T$. chebula (3 kg), and lemon fruit (10 number) were used for preparing traditional formulation. Powder of dried fruits of $T$. chebula was thoroughly mixed with cow urine to which juice extracted from lemon fruits were added. This was kept for 15 days under shade after covering with a gunny bag. Regular stirring was also done. The formulation was sieved using a muslin cloth before the spraying. Spraying was done using a knapsack sprayer fitted with a deflector type nozzle and hood to avoid direct contact of the spray fluid to crop plants (protected spray).

The weed samples collected at 30,60 DAS, and at the harvest stage were air-dried and then oven-dried in a hot air oven at $80 \pm 2^{\circ}$ $\mathrm{C}$ to obtain a constant weight. These were ground to a fine powdered form in a Willey mill and standard procedures were used for analyzing the nitrogen (Humphries, 1956), phosphorus (Jackson, 1973), and potassium (Jackson, 1973) content. Nutrient removal by weeds were calculated by multiplying the dry matter production $\left(\mathrm{kg} \mathrm{ha}^{-1}\right)$ with respective nutrient content $(\%)$ and expressed in $\mathrm{kg} \mathrm{ha}^{-1}$.

The observed data were statistically analyzed based on the procedure given by Gomez \& Gomez (1984) to find out the treatment differences.

\section{Results}

\subsection{Nutrient removal by weeds}

Among the different weed management methods adopted, the nutrient (nitrogen, phosphorus, and potassium) removal was significantly varied during all growth stages of the crop.

\subsubsection{Nitrogen removal}

All the weed management treatments showed a noticeable influence on nitrogen removal by weeds (Table 1). At 30 DAS, lower $\mathrm{N}$ removal by weeds $\left(0.68 \mathrm{~kg} \mathrm{ha}^{-1}\right)$ was observed in hand weeding twice on 20 and 45 DAS. It was followed by POE vinegar $20 \%+$ hand weeding on 45 DAS $\left(3.09 \mathrm{~kg} \mathrm{ha}^{-1}\right)$ and POE vinegar $20 \%\left(3.65 \mathrm{~kg} \mathrm{ha}^{-1}\right)$ which were at par with each other. Hand weeding twice on 20 and 45 DAS registered significantly lower nitrogen removal ( 0.2 and $1.40 \mathrm{~kg} \mathrm{ha}^{-1}$ ) which was merely comparable with POE vinegar $20 \%+$ hand weeding on 45 DAS $\left(0.71\right.$ and $\left.1.83 \mathrm{~kg} \mathrm{ha}^{-1}\right)$ at 60 DAS and harvest. This was followed by EPOE traditional formulation @ $101 \mathrm{ha}^{-1}$ (Cow urine + Lemon fruit $+T$. chebula $)+$ hand weeding on 45 DAS (3.48 and $4.69 \mathrm{~kg}$ $\left.\mathrm{ha}^{-1}\right)$. Higher nitrogen removal of $24.49,74.92$, and $79.53 \mathrm{~kg} \mathrm{ha}^{-1}$ was observed with a weedy check at 30,60 DAS and harvest. 
Table 1 Effect of traditional weed management practices on nitrogen removal $\left(\mathrm{kg} \mathrm{ha}^{-1}\right)$ by weeds at 30,60 DAS and harvest in maize

\begin{tabular}{|c|c|c|c|}
\hline Treatment & $30 \mathrm{DAS}$ & $60 \mathrm{DAS}$ & Harvest \\
\hline EPOE $30 \%$ common salt & 16.83 & 63.84 & 67.93 \\
\hline EPOE $30 \%$ common salt $+\mathrm{HW}$ on 45 DAS & 17.26 & 9.56 & 11.21 \\
\hline POE vinegar $20 \%$ & 3.65 & 6.48 & 8.11 \\
\hline POE vinegar $20 \%+\mathrm{HW}$ on 45 DAS & 3.09 & 0.71 & 1.83 \\
\hline EPOE traditional formulation @ $101 \mathrm{ha}^{-1}($ Cow urine + Lemon + T. chebula $)$ & 10.42 & 63.46 & 67.32 \\
\hline EPOE traditional formulation @ 101 ha $^{-1}($ Cow urine + Lemon + T. chebula $)+$ HW on 45 DAS & 11.10 & 3.48 & 4.69 \\
\hline EPOE traditional formulation @ $7.51 \mathrm{ha}^{-1}($ Cow urine + Lemon + T. chebula $)$ & 16.25 & 63.99 & 68.27 \\
\hline EPOE traditional formulation @ 7.51 ha $^{-1}($ Cow urine + Lemon + T. chebula $)+\mathrm{HW}$ on 45 DAS & 15.36 & 9.37 & 10.83 \\
\hline HW twice on 20 and 45 DAS & 0.68 & 0.20 & 1.40 \\
\hline Weedy check & 24.49 & 74.92 & 79.53 \\
\hline $\begin{array}{c}\mathrm{SEd} \\
\mathrm{CD}(\mathrm{P}=0.05)\end{array}$ & $\begin{array}{l}1.02 \\
2.15\end{array}$ & $\begin{array}{l}1.30 \\
2.72\end{array}$ & $\begin{array}{l}1.13 \\
2.36\end{array}$ \\
\hline
\end{tabular}

EPOE: Early post emergence application; POE: Post emergence application; DAS: Days after sowing; HW: Hand weeding

Table 2 Effect of traditional weed management practices on phosphorus removal $\left(\mathrm{kg} \mathrm{ha}^{-1}\right)$ by weeds at 30,60 DAS and harvest in maize

\begin{tabular}{|c|c|c|c|}
\hline Treatment & $30 \mathrm{DAS}$ & 60 DAS & Harvest \\
\hline EPOE $30 \%$ common salt & 1.98 & 6.17 & 9.14 \\
\hline EPOE $30 \%$ common salt + HW on 45 DAS & 2.03 & 0.92 & 1.51 \\
\hline POE vinegar $20 \%$ & 0.43 & 0.63 & 1.09 \\
\hline POE vinegar $20 \%+\mathrm{HW}$ on 45 DAS & 0.36 & 0.07 & 0.25 \\
\hline EPOE traditional formulation @ $101 \mathrm{ha}^{-1}($ Cow urine + Lemon + T. chebula $)$ & 1.23 & 6.13 & 9.06 \\
\hline EPOE traditional formulation @ $101 \mathrm{ha}^{-1}($ Cow urine + Lemon + T. chebula $)+\mathrm{HW}$ on 45 DAS & 1.31 & 0.34 & 0.63 \\
\hline EPOE traditional formulation @ $7.51 \mathrm{ha}^{-1}($ Cow urine + Lemon + T. chebula $)$ & 1.91 & 6.18 & 9.19 \\
\hline EPOE traditional formulation @ $7.51 \mathrm{ha}^{-1}($ Cow urine + Lemon $+T$. chebula $)+\mathrm{HW}$ on 45 DAS & 1.81 & 0.91 & 1.46 \\
\hline HW twice on 20 and 45 DAS & 0.08 & 0.02 & 0.19 \\
\hline Weedy check & 2.88 & 7.24 & 10.70 \\
\hline $\begin{array}{c}\text { SEd } \\
\mathrm{CD}(\mathrm{P}=0.05)\end{array}$ & $\begin{array}{l}0.13 \\
0.28\end{array}$ & $\begin{array}{l}0.11 \\
0.24\end{array}$ & $\begin{array}{l}0.15 \\
0.32\end{array}$ \\
\hline
\end{tabular}

EPOE: Early post emergence application; POE: Post emergence application; DAS: Days after sowing; HW: Hand weeding

\subsubsection{Phosphorus removal}

Phosphorus removal by weeds was significantly influenced by traditional weed management methods and is presented in Table 2. Among the traditional weed management methods hand weeding twice on 20 and 45 DAS noted lower phosphorus removal $(0.08 \mathrm{~kg}$ $\mathrm{ha}^{-1}$ ) by weeds at 30 DAS and was followed by POE vinegar $20 \%$ + hand weeding on 45 DAS $\left(0.36 \mathrm{~kg} \mathrm{ha}^{-1}\right)$ and POE vinegar $20 \%$ $\left(0.43 \mathrm{~kg} \mathrm{ha}^{-1}\right)$ which were at on par with each other. At 60 DAS and harvest, phosphorus removal by weeds was considerably lower in hand weeding twice on 20 and 45 DAS $\left(0.02\right.$ and $\left.0.19 \mathrm{~kg} \mathrm{ha}^{-1}\right)$ and POE vinegar $20 \%+$ hand weeding on 45 DAS ( 0.07 and 0.25 $\mathrm{kg} \mathrm{ha}^{-1}$ ) which were at par with each other and followed by EPOE traditional formulation @ $101 \mathrm{ha}^{-1}$ (Cow urine + Lemon fruit $+T$. chebula $)+$ hand weeding on 45 DAS $\left(0.34\right.$ and $\left.0.63 \mathrm{~kg} \mathrm{ha}^{-1}\right)$. Phosphorus removal by weeds was significantly higher $(2.88,7.24$, and $10.70 \mathrm{~kg} \mathrm{ha}^{-1}$ ) in weedy check at all the stages of observation.

\subsubsection{Potassium removal}

All the weed management treatments showed an influence on potassium removal by weeds (Table 3). Hand weeding twice on 20 and 45 DAS recorded substantially lower potassium removal $(0.45$ $\mathrm{kg} \mathrm{ha}^{-1}$ ) by weeds at 30 DAS. It was followed by POE vinegar $20 \%$ + hand weeding on 45 DAS (2.04 kg ha $\left.{ }^{-1}\right)$ and POE vinegar $20 \%$ $\left(2.41 \mathrm{~kg} \mathrm{ha}^{-1}\right)$ which were comparable. Among the traditional weed management methods, potassium removal was significantly lower in hand weeding twice on 20 and 45 DAS ( 0.21 and $\left.1.48 \mathrm{~kg} \mathrm{ha}^{-1}\right)$ and POE vinegar $20 \%$ + hand weeding on 45 DAS (0.73 and 1.94 $\left.\mathrm{kg} \mathrm{ha}^{-1}\right)$ at $60 \mathrm{DAS}$ and harvest which were on par with each other. This was followed by EPOE traditional formulation @ $101 \mathrm{ha}^{-1}$ $($ Cow urine + Lemon fruit + Terminalia chebula $)+$ hand weeding on 45 DAS (3.59 and $4.97 \mathrm{~kg} \mathrm{ha}^{-1}$ ). Conspicuously higher removal of potassium of $16.18,77.43$, and $84.30 \mathrm{~kg} \mathrm{ha}^{-1}$ by weeds were recorded in weedy check at 30,60 DAS and harvest. 
Table 3 Effect of traditional weed management practices on potassium removal $\left(\mathrm{kg} \mathrm{ha}^{-1}\right)$ by weeds at 30, 60 DAS and harvest in maize

\begin{tabular}{|c|c|c|c|}
\hline Treatment & 30 DAS & $60 \mathrm{DAS}$ & Harvest \\
\hline EPOE $30 \%$ common salt & 11.12 & 65.98 & 72.00 \\
\hline EPOE $30 \%$ common salt $+\mathrm{HW}$ on 45 DAS & 11.41 & 9.88 & 11.89 \\
\hline POE vinegar $20 \%$ & 2.41 & 6.70 & 8.60 \\
\hline POE vinegar $20 \%+\mathrm{HW}$ on 45 DAS & 2.04 & 0.73 & 1.94 \\
\hline EPOE traditional formulation @ 101 ha $^{-1}$ (Cow urine + Lemon + T. chebula $)$ & 6.88 & 65.59 & 71.36 \\
\hline EPOE traditional formulation @ $101 \mathrm{ha}^{-1}($ Cow urine + Lemon $+T$. chebula $)+\mathrm{HW}$ on 45 DAS & 7.33 & 3.59 & 4.97 \\
\hline EPOE traditional formulation @ $7.51 \mathrm{ha}^{-1}($ Cow urine + Lemon $+T$. chebula $)$ & 10.74 & 66.13 & 72.36 \\
\hline EPOE traditional formulation @ 7.51 ha $^{-1}($ Cow urine + Lemon $+T$. chebula $)+$ HW on 45 DAS & 10.15 & 9.68 & 11.68 \\
\hline HW twice on 20 and 45 DAS & 0.45 & 0.21 & 1.48 \\
\hline Weedy check & 16.18 & 77.43 & 84.30 \\
\hline SEd & 0.69 & 1.35 & 1.43 \\
\hline $\mathrm{CD}(\mathrm{P}=0.05)$ & 1.44 & 2.84 & 3.00 \\
\hline
\end{tabular}

EPOE: Early post emergence application; POE: Post emergence application; DAS: Days after sowing; HW: Hand weeding

\section{Discussion and conclusions}

Competition between crops and weeds leads to distorted growth and development of both crop and weed species. Weeds being a serious negative factor in crop production are responsible for marked losses of crop yield. Weeds mainly compete for nutrients and are an important side of crop weed interference. The weed flora composition and method of weed control decide the extent of nutrient loss. Nutrient depletion from the soil is a function of dry weight and nutrient content in the weeds. Weeds usually grow faster than crops and thus absorb the available nutrients earlier causing want of nutrients for the crop plant. The initially slow growth of maize permitted the weeds to compete for nutrients (Ahmed, 2012).

The nutrient removal by weeds was minimum where weed control was promising (Table 1, 2, 3). In general, all the weed management treatments recorded lower removal of nutrients $(\mathrm{N}, \mathrm{P}$, and $\mathrm{K}$ ) by weeds compared to weedy check, due to the control of weeds at appropriate stages which lead to lesser weed density and dry weight at critical growth stages of crop. Variation in the nutrient removal was observed due to intensity and dry matter build-up of weeds. Hand weeding twice on 20 and 45 DAS and POE vinegar $20 \%$ + hand weeding on 45 DAS prevented further accumulation of weed dry weight by reducing weed density which lead to decreased exhaustion of soil nutrients. This was in line with the findings of Swetha (2015) and Nazreen et al. (2017). This was followed by EPOE traditional formulation @ 101 ha $^{-1}$ (Cow urine + Lemon fruit $+T$. chebula $)+$ hand weeding on 45 DAS. The allelochemicals present in $T$. chebula had a significant influence on weed seed germination in the early stage and manual removal of weeds at later period which lead to reduced dry weight and hence, reduced nutrient removal by weeds. Inhibition of weed seed germination by allelochemicals in T. chebula was also reported by Manikandan \& Rejula (2008). Groundless to say higher nutrient removal was observed in weedy check which could be attributed to lower control of weeds in this treatment (Figure 1). Similar findings were also reported by Sinha et al. (2005) and Sonawane et al. (2014).

Traditional weed management practices significantly influenced nutrient removal patterns by weeds. At 60 DAS and harvest, lower nutrient removal by weeds was observed in hand weeding twice at 20 ad 45 DAS which was comparable to POE vinegar $20 \%$ + hand weeding on 45 DAS and these indicate the suitability of traditional weed management practices for managing nutrient removal by weeds in maize. Nutrients, an important resource for crop production which otherwise extracted by the weeds in an unweeded condition can be made available to crop growth using traditional weed management practices.

\section{Conflict of interests}

The authors declare no conflict of interest.

\section{References}

Ahmed A (2012) Weed management studies in kharif maize. M.Sc. (Ag.) Thesis, Acharya NG Ranga Agricultural University, Hyderabad, India.

Gomez KA, Gomez AA (1984) Statistical Procedures for Agricultural Research. John Wiley \& Sons.

Humphries EC (1956) Mineral component and Ash analysis. In: Paech K, Tracey MV(Eds.) Modern Methods of Plant Analysis, Springer Verlag, Berlin. 
Jackson ML (1973) Soil Chemical Analysis. II Indian Reprint, Prentice Hall India Pvt. Ltd., New Delhi, India.

Lakshmi PV, Luther MM (2017) Studies on influence of herbicides on nutrient uptake and yield in maize. International Journal of Farm Sciences 7(1):37-39.

Manikandan M, Rejula M (2008) Identification of allelochemicals from Terminalia chebula. African Research Review 2(3): 306-314.

Mundra S, Was A, Maliwal P (2002) Effect of weed and nutrient management on nutrient uptake by maize (Zea mays) and weeds. Indian Journal of Agronomy 47(3): 378-383.

Nazreen S, Subramanyam D, Sunitha N, Umamahesh V (2017) Nutrient uptake of maize and its associated weeds as influenced by sequential application of herbicides. International Journal of Pure Applied Biosciences 5(6):496-500.
Sinha S, Prasad S, Singh S, (2005) Nutrient utilization by winter maize (Zea mays) and weeds as influenced by integrated weed management. Indian Journal of Agronomy 50(4):303-304.

Sivagamy K., Chinnusamy C, Parasuraman P (2017) Weed management options in transgenic stacked and non transgenic maize (Zea mays) hybrids-A review. Agricultural Reviews 38(4): 245-249.

Sonawane R, Dandge M, Kambel A, Shingrup P (2014) Effect of herbicides on nutrient uptake by weeds, crops and yield of kharif maize. Paper presented at the Biennial Conference of Indian Society of Weed Science, Jabalpur.

Swetha K (2015) Weed management with new generation herbicides in kharif maize (Zea mays L.). M.Sc. (Ag.) Thesis. Professor Jayashankar Telangana State Agricultural University, Rajendranagar, Hyderabad, India. 